\title{
Tree species diversity impacts average radial growth of beech and oak trees in Belgium, not their long-term growth trend
}

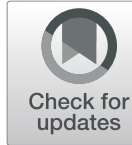

\author{
Astrid Vannoppen ${ }^{1}$, Vincent Kint ${ }^{1}$, Quentin Ponette ${ }^{2}$, Kris Verheyen $^{3}$ and Bart Muys ${ }^{1 *}$
}

\begin{abstract}
Background: Environmental change has resulted in changes in forest growth in Europe during the last century. This has consequences for the products and services delivered by forest. Mixing tree species is often proposed as a strategy to deal with the consequences of climate change. Diversifying forests is believed to result in higher productivity and increased growth stability. Tree species diversity is therefore expected to affect long-term trends in tree radial growth. However, this has not yet been studied. In this paper we study the effect of diversity on the radial growth and its long-term trends for beech and oak trees growing along a gradient of tree species diversity in the loamy region of central Belgium (from monocultures to mixed forests patches up to three species).

Results: We found that beech trees have a higher radial growth whereas oak trees have a lower one when growing in mixtures. The contrasting diversity-productivity relationship observed for beech and oak is in agreement with their ranking in shade tolerance, where oaks suffer increased competition in mixed oak patches. Overall, in monocultures and mixtures, an increasing radial growth trend of + 2\% for the period 1927-2015 and 21\% for the period 1899-2015 was found for beech and oak, respectively. Tree species diversity did not alter the shape of this detected long-term radial growth trend. Nevertheless, for oak a lower year-to-year variability in radial growth is found in mixtures indicating a higher resilience.
\end{abstract}

Conclusion: We conclude that diversity impacts the average radial growth and its variability (only in the case of oak) but not the shape of the long-term trend in radial growth of beech and oak trees growing in the loamy region of central Belgium.

Keywords: Biodiversity, Forest, Quercus robur, Fagus sylvatica, Species complementarity, Basal area increment

\section{Background}

Historical long-term radial growth changes of beech and oak trees have been reported throughout Europe (Bergès et al. 2000; Charru et al. 2017; Boisvenue and Running 2006; Kint et al. 2012). Climate change, changes in site fertility, $\mathrm{CO}_{2}$ fertilization, changes in management and tree genotypes used are identified as drivers of the reported historical radial growth changes (Hyvönen et al. 2007; Bontemps et al. 2011; Babst et al. 2013). Getting more insight in these historical radial growth changes in trees is important to predict the impact of future climate

\footnotetext{
* Correspondence: bart.muys@kuleuven.be

'Division Forest, Nature and Landscape, Department of Earth and

Environmental Sciences, University of Leuven, Celestijnenlaan 200E, Box 2411,

BE-3001 Leuven, Belgium

Full list of author information is available at the end of the article
}

change but also to assess management strategies. This is crucial since forests deliver many important ecosystem services (Thorsen et al. 2014).

A driver that to our knowledge is not yet studied in historical long-term radial growth studies is tree species diversity. Tree species diversity could have an impact on long-term radial growth trends since diverse systems are expected to function better (Loreau et al. 2001; Isbell et al. 2009). For individual trees in mixed forests, better exploitation and more efficient use of resources (niche differentiation) and interspecific facilitation, collectively referred to as complementarity effects, are mechanisms underlying this positive biodiversity ecosystem functioning relationship (Loreau and Hector 2001). Furthermore, more mixed forests are found to exhibit more stable growth patterns (Jucker et al. 2014a; del Río et al. 2017). 
Generally the relationship between biodiversity and productivity is found to be positive (Zhang et al. 2012; Liang et al. 2016). However, the diversity-productivity relationship seems to be context-dependent. Tree development stage, scale (e.g. tree level compared to stand level) and climate are found to shape the diversity-productivity relationship (Cavard et al. 2011; Chisholm et al. 2013; Forrester 2014; Jucker et al. 2016). Jucker et al. (2016) have demonstrated that the diversity-productivity relationship changes along a spatial gradient of climate. It might thus be that also along a temporal gradient of climate the diversity-productivity relationship changes. This is important since climatic conditions have been changing over the past decades and are expected to change further, which will impact forest ecosystems (Lindner et al. 2010; IPCC 2013). The stress gradient hypothesis, which states that complementarity effects are dependent on abiotic variables, including climate, proposes a climate dependency of the diversity-productivity relationship (Loreau and Hector 2001; Morin et al. 2011). Under harsh conditions the complementarity effects are expected to increase relative to competitive interactions which decrease.

Tree-ring series are often used to model long-term changes in radial growth. In order to model long-term radial growth changes, tree growth changes related to growth changes of individual trees (e.g. due to tree aging, local site characteristics or competition) must be separated from historical long-term radial growth trends. To properly assess historical radial growth changes, tree aging, an obvious driver of tree radial growth, must be taken into account, for instance via detrending or statistical modeling techniques (Peters et al. 2014). In addition, a data sample of trees which cover a wide range of developmental stages is crucial (Bontemps et al. 2010).

In this study we will look what the effect of tree diversity is on the radial growth of beech (Fagus sylvatica) and oak (Quercus robur) trees in Belgium. To this end, mean TRW and its variability over time will be evaluated for beech and oak trees growing in plots with different tree diversity levels. In a last step we will examine if there is a long-term trend in radial growth of beech and oak and if this trend is influenced by tree species diversity. By this the effect of a temporal gradient of climate on the diversity-productivity relationship will be investigated at the hierarchical scale of individual beech and oak trees.

Multilevel mixed models (Kint et al. 2012; Aertsen et al. 2014) are used in this paper to separate historical radial growth change from other factors which may influence radial growth such as tree aging, site quality and stand structure (e.g. competition level and tree species diversity). In a first step radial growth of individual trees is modelled in function of tree aging, site quality and stand structure variables (including tree species diversity). In a second step, we look if there is a change of radial growth by testing if radial growth changes with time in all trees when the individual tree growth (i.e. previous step) is accounted for. In this last step it is also tested if tree species diversity alters the long-term trend in radial growth.

\section{Methods}

\section{Study area and plot description}

Beech and oak trees growing in even-aged stands of two forests, Meerdaal and Zoniën, located in the loamy region of Belgium were studied. In total 75 and 70 plots were selected for beech and oak, respectively. The maximum distance between plots from the two forests is $23.8 \mathrm{~km}$, and $3.7 \mathrm{~km}$ and $9.3 \mathrm{~km}$ between plots within Meerdaal and Zoniën, respectively. Annual precipitation is $821 \mathrm{~mm}$ year $^{-}$

1 and mean annual temperature is $10.3{ }^{\circ} \mathrm{C}$ for the period 1901-2015. The long-term trend in annual precipitation and mean temperature is visualized in Additional file 1: Figure S1. Plots are circular (18 m radius) with a (co) dominant beech or oak tree in the center (further referred to as center tree). This center tree is the tree that was cored. Plots were selected along i) a wide range of developmental stages (Additional file 2: Figure S2) and ii) a gradient of species diversity with levels Isp, IIsp and IIIsp for plots with one, two and three tree species respectively. An admixture of at least $15 \%$ of other tree species than beech or oak was used as a threshold for the beech and oak IIsp and IIIsp plots. This threshold was considered as the absolute minimum, in the selection of the IIsp and IIIsp plots the highest possible evenness was pursued. Plots were selected in even aged stands to ensure that the center tree developed in a monoculture (i.e. Isp) or mixed environment (i.e. IIsp and IIIsp) over their whole age range. In addition, it was ensured that plots represent different tree species combinations (i.e. species composition) (Table 1).

\section{Data collection \\ Tree cores}

From the center tree (i.e. beech or oak tree) two tree cores were taken (North and South direction) in the winter of 2015 using a $5 \mathrm{~mm}$ increment corer (Suunto) at $1 \mathrm{~m}$ above ground. In addition, the DBH and bark thickness at the coring location was measured. Tree rings were made visible using a core microtome. Afterwards, tree-ring widths (TRW) were measured using a Lintab measurement system with $1 / 100 \mathrm{~mm}$ resolution. The measured TRW were checked with TSAP-Win and COFECHA software for tree-ring crossdating.

\section{Forest structure and site quality data}

In each plot the forest structure was characterized by measuring: position of each tree species with diameter at 
Table 1 Number of plots sampled for each diversity level and species composition level

\begin{tabular}{lllll}
\hline & Beech center tree plots & & Oak center tree plots \\
\hline Diversity level & Species composition & nr of plots & Species composition & nr of plots \\
IIsp & Beech & 27 & Oak & 25 \\
& Beech-hornbeam & 5 & Oak-hornbeam & 6 \\
& Beech-maple & 9 & Oak-maple & 7 \\
IIIsp & Beech-oak & 9 & Beech-oak & 8 \\
& Beech-oak-hornbeam & 8 & Beech-oak-hornbeam & 7 \\
& Beech-maple-hornbeam & 6 & Oak-maple-hornbeam & 9 \\
\hline
\end{tabular}

breast height $(\mathrm{DBH})>15 \mathrm{~cm}$, crown projection area of the center tree $\left(\mathrm{CPA}, \mathrm{m}^{2}\right)$, height of the center tree $(\mathrm{H}$, $\mathrm{m})$, total CPA of trees with diameter $\mathrm{DBH}>15 \mathrm{~cm}$ in the plot (TotCPA, $\mathrm{m}^{2}$ ), and total basal area of trees with $\mathrm{DBH}>15 \mathrm{~cm}$ in the plot (TotBA, $\left.\mathrm{m}^{2}\right)$. The crown edge in the four cardinal directions was measured for CPA. Besides the basal area of trees larger than the center tree $\left(\mathrm{BAL}, \mathrm{m}^{2}\right)$, the ratio between the diameter of the center tree and the average diameter of trees with $\mathrm{DBH}>15 \mathrm{~cm}$ in the plot (ddg), scaled Shannon diversity index $\left(\mathrm{SW}_{\mathrm{BA}}\right)$, and structural diversity index (SD) were calculated. $S W_{B A}$ quantifies the number of tree species present in the plot based on their basal area and takes the evenness into account. SD is a measure for the structural heterogeneity in the plot. $\mathrm{SW}_{\mathrm{BA}}$ and $\mathrm{SD}$ were calculated as follows:

(1) $S W_{B A}=\exp \left(-\sum_{i=1}^{S} P_{B A ; i} * \ln \left(P_{B A ; i}\right)\right)$ with $P_{B A ; i}$ $=\frac{B A_{i}}{B A_{\text {tot }}}$ and $S$ total number of species present in the plot

(2) $S D=\frac{\operatorname{StDev}\left(H_{i} \cdot C P A_{i}\right)}{\operatorname{Mean}\left(H_{i} \cdot C P A_{i}\right)}$ with $i$ the $i^{\text {th }}$ tree present in the plot (Van de Peer et al., 2017)

Site quality in each plot was characterized by measuring: $\mathrm{pH}$ (1:5 soil:solution, $0.01 \mathrm{M} \mathrm{CaCl} 2)$, organic $\mathrm{C}$ and $\mathrm{N}$ content (\%, Carlo Erba 1108 elemental analyzer), derived $\mathrm{C} / \mathrm{N}$ ratio, bulk density $\left(\mathrm{g} / \mathrm{cm}^{3}\right.$ ) and texture (fraction clay, loam and sand in \%) on a composite soil sample. Composite soil sample consisted of a sample taken in N, NE, SE, SW and NW direction at $5 \mathrm{~m}$ from the center tree with a gauge $(0-30 \mathrm{~cm}$ of the mineral soil horizon) in each plot.

\section{Analysis of diversity effects}

\section{Effects of diversity on tree-ring width, forest structure and} site quality

To evaluate the effect of diversity on the growth of beech and oak, chronologies of raw (referred to as TRW) and individually detrended tree-ring width series (referred to as RWI) were built for the three diversity levels (Isp, IIsp and IIIsp). A 15-year cubic smoothing spline with a $50 \%$ frequency cutoff was used for detrending in order to remove non-climatic low frequency variability such as for example age trends. The average growth rates (AGR), inter-series correlation (Rbar) and expressed population signal (EPS) are reported for each chronology. The EPS is a measure to evaluate the quality of a chronology and is based on Rbar and number of samples. A non-parametric Dunn test was used to test if chronologies of the three diversity levels differed significantly for both beech and oak.

For each species composition level chronologies were built using the same methodology as for the chronology building at species diversity level. A non-parametric Dunn test was used to test if radial growth is significantly different between the chronologies of different species composition level. For consistency, the chronologies were built using the same dataset as was used for the long-term radial growth modeling (i.e. first 30 years are removed and time period is 1927-2015 and 18992015 for beech and oak, respectively).

For the forest structure and site quality variables a parametric Tukey or non-parametric Dunn test (in case of non-normality of the tested variable) was used to test if variables differed significantly between the three diversity levels. The significance level was set to 0.05 for the Dunn and Tukey tests.

\section{Long-term radial growth trends}

A mixed modeling strategy was used to model the long-term radial trends in basal area increment (BAI) a measure for tree radial growth. BAI was calculated as:

$$
B A I_{t}=\pi\left(R_{t}^{2}-R_{t-1}^{2}\right)
$$

With $\mathrm{R}$ the tree radius at the end of the growing season in year $t$ (derived from cumulative TRW measurements). The juvenile developmental stage (first 30 years) was excluded from the analysis and BAI was natural log transformed to deal with the skewed distribution. The modeling is started from this year wherefore data from 
at least ten trees were available (1927 and 1899 for beech and oak, respectively).

The models were built in two sequential stages. First base models $(\mathbf{M b})$ which describe the BAI in function of developmental stage, forest structure and site quality were built. Previous year diameter $(\mathrm{Dp}, \mathrm{cm})$ was chosen to characterize the developmental stage since it is known that tree growth is more driven by tree size than cambial age (Mencuccini et al. 2005; Wykoff 1990). Possible forest structure and site quality variables were selected a priori using multiple regression (Additional file 3: Table S1). Besides, it was ensured that the selected forest structure and site quality variables had a variance inflation factor $<5$. For the mixed modeling the methodology of Zuur et al. (2009) was used. Random effects included are: random intercept for tree and random slope related with Dp. The significance level was set to 0.001 for the selection of the fixed effects. The base models describe the BAI of individual trees. In order to see if BAI varies with calendar date in all trees it is tested if a linear, quadratic, cubic or natural cubic spline term of calendar year improves the base models, the result are the date models (Md). The term related with calendar year in the date models describe long-term radial growth changes caused by exogenous factors. Interaction between the term related with calendar year and the forest structure and site quality variables that were found to be significant in the $\mathbf{M b}$ models were also tested. Only the Md models will be reported since the focus of this paper are long-term radial growth trends.

Final models were fitted with restricted maximum likelihood (REML) and their model performance was evaluated with pseudo- $\mathrm{R}^{2}$ of full and marginal model (i.e. only considering fixed effects) and relative root mean squared error (rRMSE, calculated for response). The pseudo- $\mathrm{R}^{2}$ was calculated as the correlation between the response and model predictions. All statistics were performed in $\mathrm{R}$ (version 3.2.5) ( $\mathrm{R}$ Development Core Team 2016) with packages "nlme", "spline" and "dplr" (Bunn 2008; Hothorn et al. 2008; Pinheiro et al. 2016).

\section{Results}

Evaluation of effect of diversity on tree-ring width, forest structure and site quality

A higher TRW is found for beech trees growing in more diverse plots, the opposite is true for oak trees, which grow better in monoculture plots (Additional file 4: Table S2, Fig. 1 and Table 2). TRW is significantly higher in IIsp versus Isp, IIIsp versus Isp and IIIsp versus IIsp plots for beech. TRW is significantly lower in IIsp versus Isp, IIIsp versus Isp and IIIsp versus IIsp for oak. The first order autocorrelation is significantly higher in IIsp versus Isp and IIIsp versus Isp plots for oak $(p<0.05)$. For beech trees the first order autocorrelation increases with plot diversity level but no significant differences are found $(p>0.05)$ (Table 2).

Beech TRW is significantly different between all species composition levels except for species composition levels beech versus beech-hornbeam, beech-maple-hornbeam versus beech-oak, beech-maple-hornbeam versus beech-maple-oak, and beech-maple versus beech-oak-hornbeam (Fig. 2).

Oak TRW is significantly different between all species composition levels except for species composition levels oak-beech versus oak-beech-hornbeam, oak versus oak-hornbeam, oak-beech versus oak-maple-beech, oak-maple versus oak-maple-beech and oak-maple versus oak-maple-hornbeam (Fig. 2).

$\mathrm{SW}_{\mathrm{BA}}$ is significantly higher in more diverse plots for both beech and oak (Fig. 3 and Additional file 5: Table S3). For oak significant differences are found in BAL, TotBA and TotCPA (Fig. 3 and Additional file 5: Table S3). No significant differences are found in the site quality variables and other forest structural variables between plots of different diversity level for both beech and oak.

\section{Long-term radial growth trends in beech and oak along a diversity gradient}

A long-term trend in radial growth is found for beech and oak center trees (Table 3). Tree developmental (i.e. Dp) stage is present in the models for beech and oak as a quadratic polynomial fixed effect, indicating that tree growth increases until a certain $\mathrm{Dp}$ afterwards radial growth levels off. A random intercept for tree and a random slope associated with Dp resulted in the best random structure for both beech and oak models.

For beech a cubic term of calendar year results in the best model fit. $\mathrm{SW}_{\mathrm{BA}}$ and BAL have a positive and negative effect, respectively, on the radial growth of beech. Other forest structural variables and site quality variables are not significant (Table 3). The interaction of $\mathrm{SW}_{\mathrm{BA}}$ and the cubic term of calendar year is not significant, indicating that the long-term trend in radial growth does not change for beech trees growing in plots with different diversity levels. Nonetheless the presence of $\mathrm{SW}_{\mathrm{BA}}$ in the model indicates a positive effect of diversity on radial growth.

In the oak model a quadratic term of calendar year results in the best model fit. The model indicates that oak trees growing in plots with high BAL have lower radial growth (i.e. negative estimate for BAL) (Table 3). Other forest structure or site quality variables do not influence radial growth significantly.

The model evaluation parameters of the models are good. The difference between the $\mathrm{R}^{2}$ of the full model and marginal model (i.e. $R^{2} f$ and $R^{2} m$ ) indicate that large part of the variability is explained by the random effects. The non-significant correlation between tree size and 

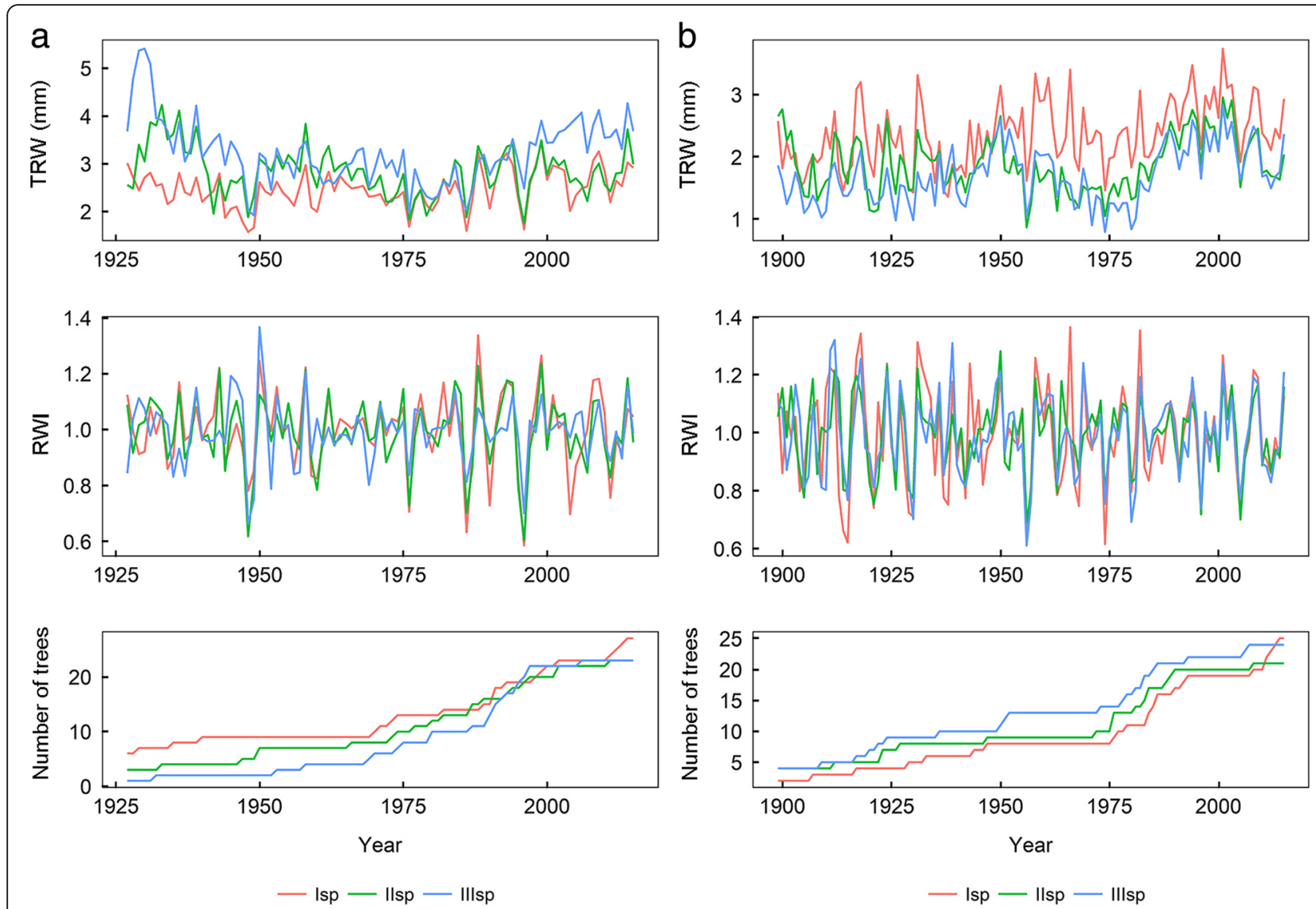

Fig. 1 Chronologies of TRW and RWI for beech (a) and oak (b) center trees. Number of trees used for the chronology building is presented in the bottom graphs. See Additional file 9: Table S5.S2 for the Dunn test on TRW

the random components of the models indicate the effect of tree size on growth is well modelled by the quadratic polynomial of $\mathrm{Dp}$.

The detected long-term radial growth trends for beech and oak are visualized in Fig. 4. Relative to the radial growth in 1927 beech radial growth decreases until 1957 (-25\% from 1927 to 1957$)$ where after it increases again (+27\% from 1957 to 2015). An overall growth increase of $2 \%$ for the period 1927-2015 is detected for beech. The date model of beech predicts radial growth to be $23 \%$ and $54 \%$ higher for beech trees growing in plots with $S W_{\mathrm{BA}}$ equal to two (i.e. a plot with two tree species with perfect evenness) and three (i.e. a plot with three tree species with perfect evenness) compared to $\mathrm{SW}_{\mathrm{BA}}$ equal to one (i.e. a plot with one tree species), respectively. Relative to the radial growth in 1899, oak radial growth decreases until 1940 after this it increases again. Overall the oak radial growth increased with $21 \%$ for the period 1899-2015.

\section{Discussion \\ Diversity influences radial growth of beech and oak differently}

Our results indicate that tree species diversity has an opposite effect on radial growth of beech versus oak. Beech trees growing in diverse stands have higher radial growth whereas oak trees have lower radial growth (Additional file 4: Table S2, Fig. 1 and Table 2). Note that DBH and

Table 2 Characteristics of TRW chronologies for beech and oak center trees growing in plots with tree diversity level Isp, IIsp or IIIsp

\begin{tabular}{|c|c|c|c|c|c|c|c|c|}
\hline \multicolumn{5}{|l|}{ Beech } & \multicolumn{4}{|l|}{ Oak } \\
\hline Diversity level & Rbar' & $\mathrm{EPS}^{1}$ & AGR (mm) & $\overline{\text { Lag-1 }}$ & $\overline{\mathrm{Rbar}^{1}}$ & EPS $^{1}$ & AGR (mm) & $\overline{\text { Lag-1 }}$ \\
\hline Isp & 0.341 & 0.874 & $2.472^{a}$ & $0.408^{d}$ & 0.399 & 0.865 & $2.359^{e}$ & $0.406^{h}$ \\
\hline$\| s p$ & 0.272 & 0.807 & $2.838^{\mathrm{b}}$ & $0.518^{d}$ & 0.307 & 0.831 & $1.876^{f}$ & $0.609^{i}$ \\
\hline IIIsp & 0.154 & 0.630 & $3.233^{c}$ & $0.706^{d}$ & 0.341 & 0.873 & $1.699^{9}$ & $0.643^{i}$ \\
\hline
\end{tabular}

Rbar Interseries correlation, EPS Expressed population signal, AGR Average growth rate, lag-1 First year autocorrelation, 1 referring to detrended TRW data. For variables AGR and Lag-1, the diversity levels without common letters differ significantly at $\mathrm{p}<0.05$ 

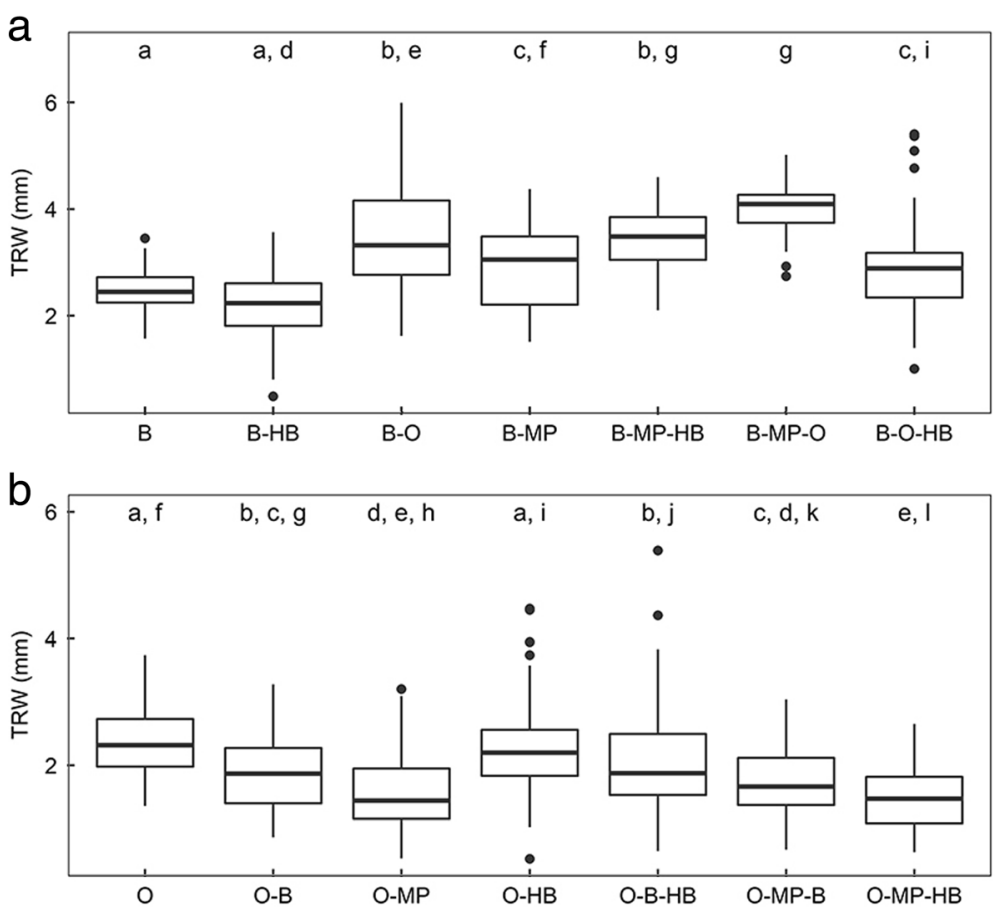

Fig. 2 Boxplots of TRW chronologies at each species composition level for beech (a) and oak (b) center trees. O: oak, B: beech, HB: hornbeam and MP: maple. Composition levels without common letters differ significantly at $p<0.05$ (Additional file 9: Table S5.S3)
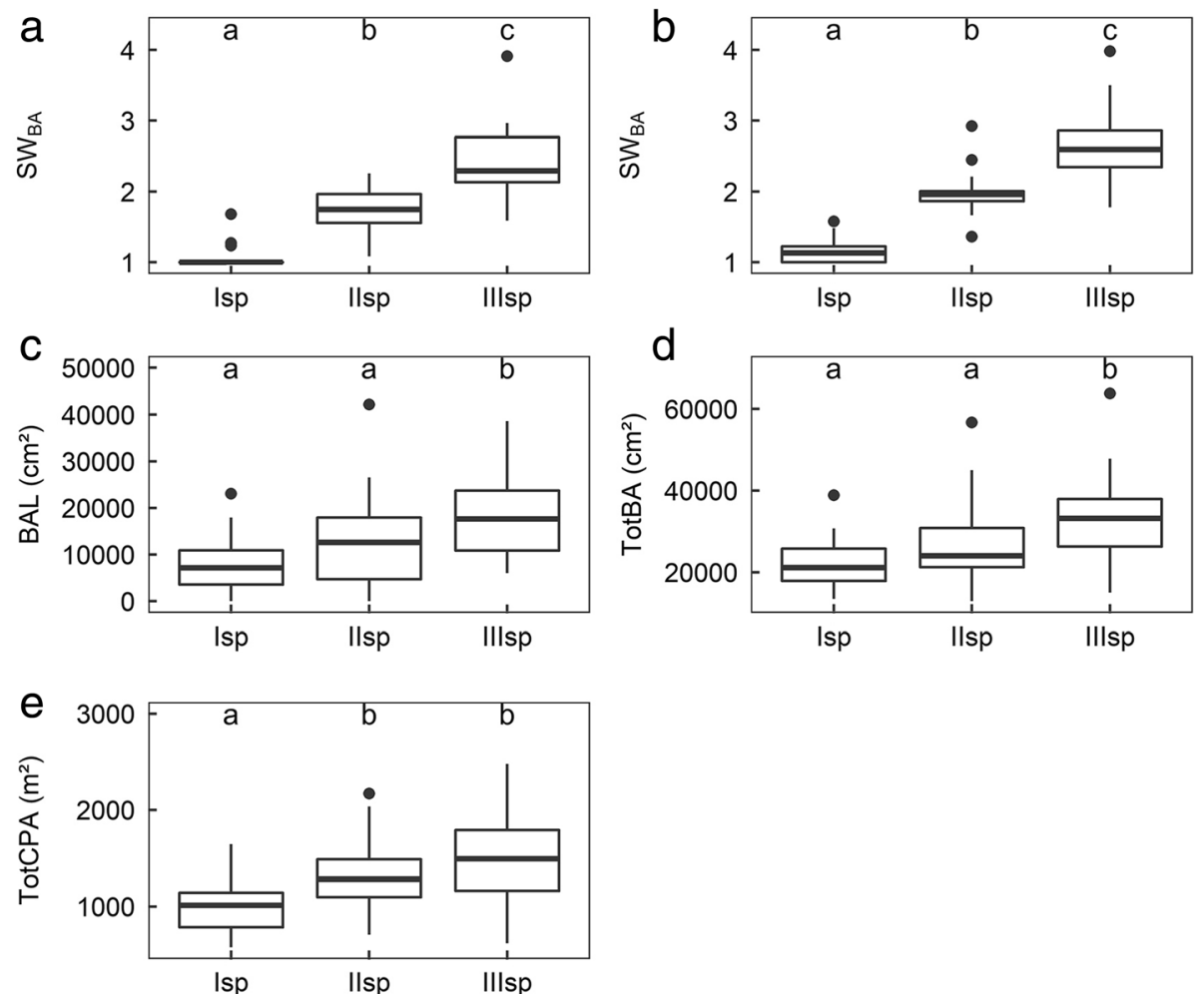

Fig. 3 Boxplots of forest structure variables for beech (a) and oak (b-e) center trees. Diversity levels without common letters differ significantly at $p<0.05$. SWBA: scaled Shannon diversity index, BAL: basal area of trees larger than the center tree, TotBA: total basal area of trees with DBH $>15$ $\mathrm{cm}$ in the plot, and TotCPA: total CPA of trees with diameter DBH $>15 \mathrm{~cm}$ in the plot 
Table 3 Parameter estimates and model evaluation of the In (BAI) date models for beech and oak

\begin{tabular}{|c|c|c|c|c|c|c|c|c|}
\hline \multicolumn{5}{|l|}{ Beech $(n=3095)$} & \multicolumn{2}{|c|}{ oak $(n=3978)$} & \multirow[t]{2}{*}{ Df } & \multirow[t]{2}{*}{$p>|t|$} \\
\hline Fixed effects & Estimate & SE & Df & $p>|t|$ & Estimate & SE & & \\
\hline Intercept & 3.4389 & 0.1030 & 2941 & $<0.0001$ & 8.0459 & 0.0620 & 3904 & $<0.0001$ \\
\hline poly $(D p)^{1}$ & 11.0569 & 2.7688 & 2941 & 0.0001 & 12.2897 & 2.9592 & 3904 & $<0.0001$ \\
\hline poly $(D p)^{2}$ & -16.1505 & 1.5582 & 2941 & $<0.0001$ & -10.0370 & 1.5731 & 3904 & $<0.0001$ \\
\hline BAL & $-2.1 * 10^{-5}$ & $3.2^{*} 10^{-6}$ & 70 & $<0.0001$ & $-1.80 * 10^{-5}$ & $3.1^{*} 10^{-6}$ & 68 & $<0.0001$ \\
\hline$S W_{B A}$ & 0.2054 & 0.0528 & 70 & 0.0002 & & & & \\
\hline poly (year) ${ }^{1}$ & 4.3896 & 1.2802 & 2941 & 0.0006 & 4.6529 & 1.2740 & 3904 & 0.0003 \\
\hline poly $(\text { year) })^{2}$ & 3.0445 & 0.8343 & 2941 & 0.0003 & 2.7191 & 0.8727 & 3904 & 0.0018 \\
\hline poly (year) ${ }^{3}$ & -1.6641 & 0.7491 & 2941 & 0.0264 & & & & \\
\hline \multirow[t]{2}{*}{ SE random effect } & Intercept & $D p$ & error & & Intercept & $\mathrm{Dp}$ & error & \\
\hline & 0.6272 & 0.0015 & 0.3993 & & 0.2220 & 0.0007 & 0.3799 & \\
\hline \multirow[t]{2}{*}{ Model evaluation } & $R^{2} f$ & $R^{2} m$ & rRMSE & $\mathrm{AIC}$ & $R^{2} f$ & $R^{2} m$ & rRMSE & AIC \\
\hline & 0.644 & 0.397 & 11.159 & 2208 & 0.580 & 0.351 & 3.014 & 1573 \\
\hline
\end{tabular}

$\mathrm{Dp}$ (previous year diameter, $\mathrm{cm}$ ), BAL (basal area of trees larger than the cored tree, $\mathrm{m}^{2}$ ), $\mathrm{SW}_{\mathrm{BA}}$ (scaled Shannon diversity index), poly (Dp) and poly (year) estimates of orthogonal polynomial of $D p$ and year respectively with superscript indicating the degree, $R^{2} f$ (pseudo- $R^{2}$ of the full model), $R^{2} m$ ( $p s e u d o-R^{2}$ of the marginal model), rRMSE (relative root mean squared error) and AIC (Akaike Information Criteria)
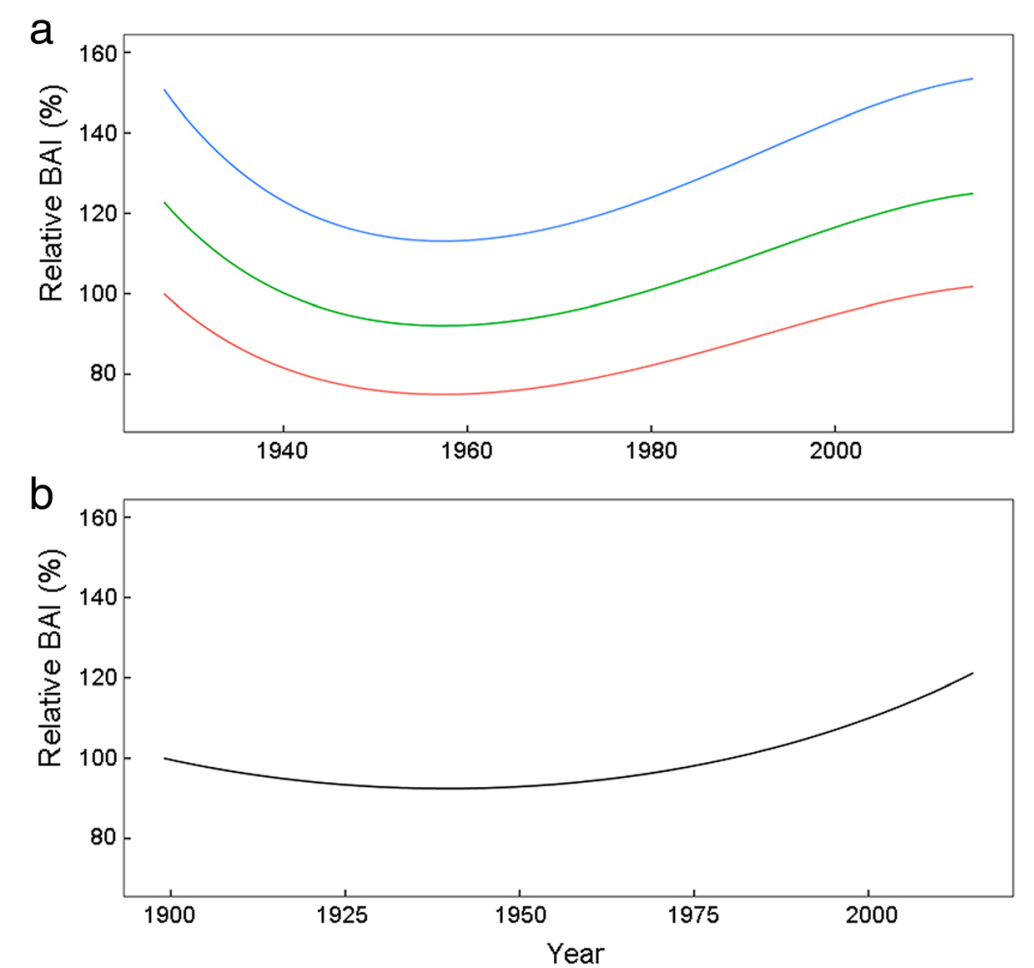

Fig. 4 Visualization of the long-term trend in radial growth for beech (a) and oak (b) center trees. BAl is predicted by the date models for a tree with constant Dp and BAL (median values from 1927 and 1899 for beech and oak respectively). For the prediction of beech BAl, SWBA was set to one (red), two (green) and three (blue) (representing plots with one, two and three tree species with perfect evenness, respectively) to visualize the effect of diversity on beech radial growth. Values are presented relative to the predicted BAI in 1927 of a tree growing in a plot with SWBA equal to one for beech and 1899 for oak 
height of the beech and oak center trees did not differ significantly between the three species diversity levels, indicating that the difference in radial growth found is not related to differences in developmental stage of the center trees for the three species diversity levels.

The difference in the reported diversity-productivity relationship of beech and oak can be related to differences in the functional traits of the tree species in the mixtures. The functional traits of the species in mixture give us information on the complementarity in resources use of tree species present in a mixture. This gives us insight in the underlying mechanisms of the diversity productivity relationship and hence its outcome.

The shade tolerance of the species in a mixture is an important trait explaining the effect of diversity, both magnitude and direction, on the productivity of trees in the mixture (Zhang et al. 2012; Jucker et al. 2014b; Toïgo et al. 2017). The shade tolerance indices of the species present in the mixture range from 2.45, 3.73, 3.97 to 4.56 for oak, maple, hornbeam and beech respectively (Ninemets and Valladares 2006). Oak is thus the most shade intolerant species whereas beech is the most shade tolerant tree species in the mixtures studied. High interspecific competition for light in the studied mixtures is probably an important factor explaining the negative effect of diversity on the shade intolerant oak compared to the positive effect of diversity on the shade tolerant beech (Toïgo et al. 2017). The shade tolerant beech is also known to be able to adapt its crown structure to increase light interception in mixed stands (i.e. crown plasticity), interspecific competition for light is thus not likely to affect its radial growth negatively when mixed with other tree species (Dieler and Pretzsch 2013).

Not only competition for light can explain the positive effect of diversity on radial growth of beech. In addition, other mechanisms might play a role here such as complementarity for water. In an ongoing study in the same study area, we found that beech trees growing in diverse stands have higher stomatal conductance, indicating higher water availability, compared to beech trees growing in monocultures in dry years. In addition, facilitation effects occur, oak for example has hydraulic redistribution properties (i.e. deep rooting tree species move water from deeper soil layers upwards) (Hafner et al. 2017).

Competition might explain the negative effect of diversity on radial growth of oak. The significantly higher TotCPA and TotBA in mixed compared to monoculture plots is likely to shape the diversity-productivity relationship (Fig. 3) (Forrester 2014). The spatial arrangement and density in stands has an influence on the interactions between tree species. The significantly higher BAL in the mixed stands indicate higher competition compared to monoculture plots (Fig. 3). This higher competition, related with the higher stand densities, may outweigh complementarity interactions in the mixed stands (Forrester 2014). Note that diversity can increase stand density, especially in cases where species with complementary traits are mixed, which is the case here (Pretzsch and Biber 2016).

Although radial growth is lower for oak trees growing in diverse stands, the first order autocorrelation is significantly higher (Table 2). This higher first order autocorrelation indicates that the year-to-year variability in radial growth is lower for oak trees growing in mixed plots, indicating a higher resilience. Likewise for beech a higher first order autocorrelation is found, although it is not significant.

When we look at the beech-oak mixture, the mixture with the highest difference in shade tolerance indices, we see that in this beech-oak mixture beech has a higher radial growth opposed to oak which has a lower radial growth compared to the monoculture of the respective tree species (Fig. 2). This highlights the importance of scale, at the stand scale the lower growth of one species might be outweighed by the higher growth of another tree species which would result in a positive effect of biodiversity on productivity (Toïgo et al. 2017).

\section{Long-term radial growth trends in beech and oak along a diversity gradient}

For beech a radial growth increase is found for the period 1927-2015 (Fig. 4). When we look at the difference quotient of the modeled long-term trend in radial growth we see that until 1957 growth decreases and that afterwards growth increases until 2015 (Additional file 6: Figure S3). The growth decline of beech from 1927 to 1957 coincides with a period of consecutive years with relative (compared to the four previous years) negative growth change (Fig. 4 and Additional file 7: Figure S4). The occurrence of multiple warm events between 1930's and 1950's may account for the observed growth decline (Additional file 8: Figure S5) (cf. Bontemps et al. 2011 on beech trees growing in north-eastern France). After 1957 radial growth increases, however the increase starts to diminish from 1993 onwards (Additional file 6: Figure S3). If this trend continues, beech radial growth will be lower compared to 1927 in a near future. In other studies a recent growth decline for beech has already been reported (Jump et al. 2006; Piovesan et al. 2008; Kint et al. 2012; Charru et al. 2017).

The positive estimate of $\mathrm{SW}_{\mathrm{BA}}$ and the negative estimate of BAL in the beech model indicate that complementarity effects alleviate negative effects of competition on radial growth. For $\mathrm{SW}_{\mathrm{BA}}$ equal to two or three (i.e. representing two and three species plots with perfect evenness, respectively) the BAL must be larger than 19,514 and $29,271 \mathrm{~cm}^{2}$ (or 20 and $29 \mathrm{~m}^{2} / \mathrm{ha}$ ), respectively, to outweigh the 
positive effect of $\mathrm{SW}_{\mathrm{BA}}$ completely. This is the case for $40 \%$ and $8 \%$ of two and three species plots, respectively. Note that in these plots the negative competition effect on the radial growth of the beech center tree is still reduced by the diversity effect (i.e. positive estimate for $\mathrm{SW}_{\mathrm{BA}}$ ) compared to the monoculture plots of beech. Diversity thus has a positive impact on beech radial growth. Even though, the non-significance of the interaction between $\mathrm{SW}_{\mathrm{BA}}$ and the long-term trend indicates that the temporal gradient in climate did not influence the diversity-productivity relationship with time.

The detected decline in oak radial growth from 1899 to 1940 coincides with periods of extreme winter frost, drought and insect outbreaks (Fig. 4 and Additional file 6: Figure S3) (Delatour 1983; Thomas et al. 2002). After 1940 oak radial growth increases and this increase is still becoming larger and larger every year (Additional file 6: Figure S3). BAL has a negative effect on the radial growth of oak. As discussed in the previous section the higher competition in the diverse oak plots probably outweighs the complementarity effects in the diverse stands. The oak model indicates that diversity has no direct influence on the radial growth of oak and thus also does not influences the detected long-term trend despite the lower year-to-year variability in radial growth of oak growing in diverse stands (Tables 2 and 3).

\section{Factors influencing long-term trends in radial growth}

The growth of trees is influenced by climate, site fertility, stand structure and management. All these factors can change gradually with time and thus explain the long-term trends in radial growth observed for beech and oak trees (Fig. 4). However, it is not possible to demonstrate causality between the gradual change in drivers of radial growth (e.g. climate, site fertility, stand structure and management) and the observed long-term trend in radial growth changes with only observational data collected in a single region (cf. Verheyen et al. 2017). In this study we tried to minimize the effect of unbalances in tree size of the sampled trees and historical changes in stand characteristics on the modeled long-term growth trends. Plots were selected along a wide range of developmental stages in order to exclude the influence of tree size on the detected long-term growth trend. The non-significance $(p>0.05)$ of the Pearson correlation between the random components and the size of the trees indicate that the mixed models used are able to capture the effect of tree size on growth. This is because a significant correlation would indicate that the growth is modeled differently for trees with different size. Plots were selected based on the species composition in the plot at the time of sampling. Despite selecting plots in even aged stands to ensure that the center tree developed in a monoculture (i.e. Isp) or mixed environment (i.e. IIsp and IIIsp) over their whole age range we cannot guarantee that the species composition was the same in the past. In addition, we assume that past management was the same in the monocultures and mixed plots.

Although the main focus of the present study is to quantify the impact of tree species diversity on average and long-term radial growth, comparison of the modeled long-term growth trends with other studies in the same area is valuable. For beech trees growing in whole Flanders (northern Belgium) a recent growth decline was detected by Kint et al. (2012). This recent negative growth decline was found to be related to increased nitrogen (N) deposition and drought over time (Kint et al. 2012). The absence of the recent growth decline in the present study indicates that the increased $\mathrm{N}$ deposition and drought over time did not impact beech trees growing in Meerdaal and Zoniën forest that much compared to beech trees growing in other parts of Flanders. Note, however, that the observed growth increase starts to diminish from 1993 onwards as mentioned earlier. The absence of the recent growth decline for beech in Meerdaal and Zoniën forest compared to whole Flanders can be explained by several factors.

First, Meerdaal and Zoniën forest are located on the loess belt in Flanders on some of the most productive sites for beech of Flanders. The good water holding capacity of the loamy soil in these forests can explain why the increased drought did not affect beech radial growth as much compared to beech growth in other regions of Flanders (Aertsen et al. 2014). Second, the studied forests are located in an area of Flanders which has lower $\mathrm{N}$ deposition compared to other forested areas in Flanders (Verstraeten et al. 2012; VMM 2017). The negative effects of high $\mathrm{N}$ deposition observed in several studies in Europe are thus probably not as severe in Meerdaal and Zoniën. Lastly, shifts in management may influence the detected long-term radial growth trend. Changes in management are often not considered in studies looking at long-term trends in radial growth since historical information on management is often missing (but see Bontemps et al. (2010)). However, this is important since changes in management result in changes in interactions between tree species and the forest structure which affect tree radial growth (Altman et al. 2013; Trouvé et al. 2015). After thinning a so-called growth release is often observed resulting from increased light availability. Therefore shifts in management to more intensive thinning will result in higher radial growth. Both in Meerdaal and Zoniën forest a tendency of increased thinning is observed in time (Huvenne P., personal communication 8/03/2018), this probably contributed to the observed increase in radial growth of beech and oak in these two forests. Note that possible shifts in historical 
management probably did not influence the long-term trend detected in the study of Kint et al. (2012). Since this study covers a broader geographical scale (i.e. northern Belgium) local effects on long-term trends in radial growth, such as shifts in management, are reduced to a minimum since forest management history is different among administrative regions.

When we look in detail to the long-term trends for beech reported by Aertsen et al. (2014), which was performed in Zoniën and Meerdaal forests, and the present study some differences in trends are observed, especially in recent decades (Additional file 9: Figure S6a). Long-term trends detected by regional curve standardization (RCS, as described by Bontemps and Esper 2011), another frequently used method to detect long-term trends in radial growth, resulted in similar long-term trends compared to the long-term trend detected by the multilevel mixed models used in both studies (i.e. Aertsen et al., (2014) and this study) (Additional file 9: Figure S6). There is thus no effect of the method used on the detection of the long-term trend. When in both datasets data points of trees at DBH $<146.3 \mathrm{~mm}$ and $>273.3 \mathrm{~mm}$ (first and third quantile respectively) are excluded in order to exclude imbalances in developmental stage with time, the long-term trends detected are more alike (Additional file 9: Figure S6b). This highlights the importance of sampling trees along a wide range of developmental stages in long-term growth trends studies. Note that the first and last time points have a large impact on the shape of the detected long-term trend by RCS. The last year (i.e. 2008) in the dataset of Aertsen et al. (2014) coincide with years with lower growth compared to other years which pulls the fitted cubic polynomial down (Additional file 9: Figure S6). The dataset of the present study also contains data after the dip in radial growth around 2008, resulting in a long-term trend that still increases after 2008.

The observed long-term growth increase observed for oak is in line with other studies in Belgium (Kint et al. 2012; Vannoppen et al. 2018). Oak is thus still profiting from environmental changes. Especially late frost is known to affect oak growth negatively, over the last decades the last day of frost occurs earlier in the year which is positive for oak growth (Tricot et al. 2015).

\section{Conclusion}

The diversity-productivity relationship is found to be influenced by the functional trait structure of the studied mixtures and the stand density. The shade tolerance can explain the contrasting diversity-productivity relationship found for beech and oak. Radial growth of beech, which has a high shade tolerance, increased when growing in mixtures. Whereas for oak, which has a low shade tolerance, radial growth decreased when growing in mixtures. The higher stand densities in oak mixed plots resulted in higher competition levels which overruled the diversity effect. Both for beech and oak an increasing long-term growth trend is observed. The growth increase is smaller for beech compared to oak, 3 and $27 \%$ for the period 1927-2015 and 1899-2015 respectively. Tree species diversity did not influence the shape of the long-term trends detected in beech and oak. However, the lower year-to-year radial growth variability in more diverse plots of both beech (although not significant) and oak (significant) suggest that under harsher environmental conditions diversity might shape long-term trends in beech and oak growth.

\section{Additional files}

Additional file 1: Figure S1. Mean yearly temperature (T mean) and cumulative precipitation (P) for the study area. Line visualizes the longterm trend of $T$ mean and $P$ through time (loess smoother). Dots are the yearly observed $T$ mean and $P$ at the climatic station of Ukkel located at 5 to $26 \mathrm{~km}$ distance from the plots (Royal Meteorological Institute of Belgium, RMI). (JPG 352 kb)

Additional file 2: Figure S2. Distribution of $\mathrm{DBH}$ at different year intervals of beech (a) and oak (b) center trees. Boxplots are based on the dataset used for modeling (i.e. juvenile growth (first 30 measured rings of each tree) is removed and start year is the year with at least data from 10 trees). (JPG $571 \mathrm{~kb}$ )

Additional file 3: Table S1. Selected forest structural and site quality variables for beech and oak center trees by multiple regression. (DOCX $14 \mathrm{~kb}$ )

Additional file 4: Table S2. $z$ and $p$-values of the Dunn test performed on the TRW chronologies. (DOCX $13 \mathrm{~kb}$ )

Additional file 5: Table S3. $z$ and $p$-values of the Dunn test for forest structure variables. (DOCX $14 \mathrm{~kb}$ )

Additional file 6: Figure S3. Difference quotient of modeled long-term radial growth trend for beech (a) and oak (b). Negative values indicate decreases in radial growth trend. Positive values indicate increases in radial growth trend. The difference quotient is calculated for time steps of 1 year as ((modeled growth in year $\mathrm{t}$ )-(modeled growth in year $\mathrm{t}-1)) / 1$ for each year t. (JPG 259 kb)

Additional file 7: Figure S4. Relative change of TRW in each year for beech center trees. TRW in each year is compared to the mean TRW in the respective 4 previous years. (JPG $278 \mathrm{~kb}$ )

Additional file 8: Figure S5. Precipitation and mean temperature anomalies for the period June to August for the period 1927-2015. Data are from the climatic station of Ukkel located at 5 to $26 \mathrm{~km}$ distance from the plots (Royal Meteorological Institute of Belgium, RMI). P: recipitation, Tmean: mean temperature, JJA: June to August (JPG $453 \mathrm{~kb}$ )

Additional file 9: Figure S6. Radial growth chronologies estimated with regional curve standardization method. Chronologies are smoothed with a cubic spline smoother (blue lines). RCS is applied on data of this study (dotted line) and on the data of Aertsen et al. (2014) (full line). Panel (b) visualizes the regional curve standardization (RCS) applied on the datasets where data points of trees at DBH $<146.3 \mathrm{~mm}$ and $>273.3$ $\mathrm{mm}$ (first and third quantile respectively) are excluded to minimize effect of tree developmental stage. (JPG $455 \mathrm{~kb}$ )

\section{Abbreviations}

AGR: Average growth rate; AIC: Akaike Information Criteria; BAI: Basal area increment; BAL: Basal area of trees larger than cored tree; CPA: Crown projection area of the cored tree; DBH: Diameter at breast height; ddg: Ratio between the diameter of the cored tree and the average diameter of trees with $\mathrm{DBH}>15 \mathrm{~cm}$ in plot; e.g.: Examplia gratia; EPS: Expressed population signal; Fig.: Figure; i.e.: Id est; JJA: June to August; Mb: Base model; Md: Date model; N: Nitorgen; $\mathrm{n}$ : Number of observations; P: Precipitation; $\mathrm{R}^{2} \mathrm{~m}$ : Pseudo- 
R square marginal model; $R^{2}$ f: pseudo-R square full model; sd: stadard deviation; Rbar: Inter-series correlation; RCS: Regional curve standardization; REML: Restricted maximum likelihood; RMSE: Root mean square error; rRMSE: Relative root mean square error; SD: Structural diversity index; SW $W_{B A}$ : Scaled Shannon diversity index based on basal area; $T$ mean: Mean yearly temperature; TotBA: Total basal area of trees with $\mathrm{DBH}>15 \mathrm{~cm}$ in the plot; TotCPA: Total CPA of trees with DBH $>15 \mathrm{~cm}$ in the plot; TRW: Tree-ring width

\section{Acknowledgements}

We would like to thank Jorgen Op De Beeck, Eric Van Beek and Remi Chevalier for their technical support. Climatic data were made available by the Royal Meteorological Institute of Belgium.

\section{Funding}

This research received funding from FWO Vlaanderen [grant number: G.0C96.14N].

\section{Availability of data and materials}

The datasets analysed during the current study are available from the corresponding author on reasonable request.

\section{Authors' contributions}

AV collected and analysed the data and was a major contributor in writing the manuscript. VK, QP, KV and BM made substantial contributions to the conception and design, the interpretation of data and writing of the manuscript. All authors read and approved the final manuscript.

\section{Ethics approval and consent to participate}

Not applicable.

\section{Consent for publication}

Not applicable.

\section{Competing interests}

The authors declare that they have no competing interests.

\section{Author details}

'Division Forest, Nature and Landscape, Department of Earth and Environmental Sciences, University of Leuven, Celestijnenlaan 200E, Box 2411, BE-3001 Leuven, Belgium. 'Earth and Life Institute, Université catholique de Louvain, Croix du Sud 2, L7.05.09, BE-1348 Louvain-la-Neuve, Belgium. ${ }^{3}$ Forest \& Nature Lab, Department of Environment, Ghent University, Geraardsbergsesteenweg 267 -Gontrode, BE-9090 Melle, Belgium.

\section{Received: 24 July 2018 Accepted: 27 February 2019}

\section{Published online: 18 March 2019}

\section{References}

Aertsen W, Janssen E, Kint V, Bontemps J-D, Van Orshoven J, Muys B (2014) Longterm growth changes of common beech (Fagus sylvatica L.) are less pronounced on highly productive sites. For Ecol Manag 312:252-259. https:// doi.org/10.1016/j.foreco.2013.09.034

Altman J, Hédl R, Szabó P, Mazůrek P, Riedl V, Müllerová J, Kopecký M, Doležal J (2013) Tree-rings Mirror management legacy: dramatic response of standard oaks to past coppicing in Central Europe. PLoS One 8:e55770. https://doi.org/ 10.1371/journal.pone.0055770

Babst F, Poulter B, Trouet V, Tan K, Neuwirth B, Wilson R, Carrer M, Grabner M, Tegel W, Levanic T, Panayotov M, Urbinati C, Bouriaud O, Ciais P, Frank D (2013) Site- and species-specific responses of forest growth to climate across the European continent. Glob Ecol Biogeogr 22:706-717. https://doi.org/10. 1111/geb.12023

Bergès L, Dupouey J-L, Franc A (2000) Long-term changes in wood density and radial growth of Quercus petraea Liebl. In northern France since the middle of the nineteenth century. Trees 14:398-408. https://doi.org/10.1007/ s004680000055

Boisvenue C, Running SW (2006) Impacts of climate change on natural forest productivity - evidence since the middle of the 20th century. Glob Change Biol 12:862-882. https://doi.org/10.1111/j.1365-2486.2006.01134.x

Bontemps J-D, Esper J (2011) Statistical modelling and RCS detrending methods provide similar estimates of long-term trend in radial growth of common beech in North-Eastern France. Dendrochronologia 29:99-107. https://doi. org/10.1016/j.dendro.2010.09.002

Bontemps J-D, Hervé J-C, Dhôte J-F (2010) Dominant radial and height growth reveal comparable historical variations for common beech in North-Eastern France. For Ecol Manag 259:1455-1463. https://doi.org/10.1016/j.foreco.2010. 01.019

Bontemps J-D, Hervé J-C, Leban J-M, Dhôte J-F (2011) Nitrogen footprint in a long-term observation of forest growth over the twentieth century. Trees 25 : 237-251

Bunn AG (2008) A dendrochronology program library in R (dpIR). Dendrochronologia 26:115-124. https://doi.org/10.1016/j.dendro.2008.01.002

Cavard X, Bergeron Y, Chen HYH, Paré D, Laganière J, Brassard B (2011) Competition and facilitation between tree species change with stand development. Oikos 120:1683-1695. https://doi.org/10.1111/j.1600-0706.2011. 19294.x

Charru M, Seynave I, Hervé J-C, Bertrand R, Bontemps J-D (2017) Recent growth changes in Western European forests are driven by climate warming and structured across tree species climatic habitats. Ann For Sci 74:1-34. https:// doi.org/10.1007/s13595-017-0626-1

Chisholm RA, Muller-Landau HC, Abdul Rahman K, Bebber DP, Bin Y, Bohlman SA Bourg NA, Brinks J, Bunyavejchewin S, Butt N, Cao H, Cao M, Cárdenas D, Chang L-W, Chiang J-M, Chuyong G, Condit R, Dattaraja HS, Davies S, Duque A, Fletcher C, Gunatilleke N, Gunatilleke S, Hao Z, Harrison RD, Howe R, Hsieh C-F, Hubbell SP, Itoh A, Kenfack D, Kiratiprayoon S, Larson AJ, Lian J, Lin D, Liu H, Lutz JA, Ma K, Malhi Y, McMahon S, McShea W, Meegaskumbura M, Mohd Razman S, Morecroft MD, Nytch CJ, Oliveira A, Parker GG, Pulla S, Punchi-Manage R, Romero-Saltos H, Sang W, Schurman J, Su S-H, Sukumar R, Sun I-F, Suresh HS, Tan S, Thomas D, Thomas S, Thompson J, Valencia R, Wolf A, Yap S, Ye W, Yuan Z, Zimmerman JK (2013) Scale-dependent relationships between tree species richness and ecosystem function in forests. J Ecol 101: 1214-1224. https://doi.org/10.1111/1365-2745.12132

del Río M, Pretzsch H, Ruíz-Peinado R, Ampoorter E, Annighöfer P, Barbeito I, Bielak K, Brazaitis G, Coll L, Drössler L, Fabrika M, Forrester DI, Heym M, Hurt V, Kurylyak V, Löf M, Lombardi F, Madrickiene E, Matović B, Mohren F, Motta R, den Ouden J, Pach M, Ponette Q, Schütze G, Skrzyszewski J, Sramek V, Sterba H, Stojanović D, Svoboda M, Zlatanov TM, Bravo-Oviedo A (2017) Species interactions increase the temporal stability of community productivity in Pinus sylvestris-Fagus sylvatica mixtures across Europe. J Ecol n/a-n/a. https://doi.org/10.1111/1365-2745.12727

Delatour C (1983) Les dépérissements de chênes en Europe. Rev For 35:265-282. https://doi.org/10.4267/2042/21659

Development Core Team R (2016) R: A language and environment for statistical computing. R Foundation for Statistical Computing, Vienna

Dieler J, Pretzsch H (2013) Morphological plasticity of European beech (Fagus sylvatica L.) in pure and mixed-species stands. For Ecol Manag 295:97-108. https://doi.org/10.1016/j.foreco.2012.12.049

Forrester DI (2014) The spatial and temporal dynamics of species interactions in mixed-species forests: from pattern to process. For Ecol Manag 312:282-292. https://doi.org/10.1016/j.foreco.2013.10.003

Hafner BD, Tomasella M, Häberle K-H, Goebel M, Matyssek R, Grams TEE (2017) Hydraulic redistribution under moderate drought among English oak, European beech and Norway spruce determined by deuterium isotope labeling in a splitroot experiment. Tree Physiol 37:950-960. https://doi.org/10.1093/treephys/tpx050

Hothorn T, Bretz F, Westfall P (2008) Simultaneous inference in general parametric models. Biom J 50:346-363. https://doi.org/10.1002/bimj. 200810425

Hyvönen R, Ågren Gl, Linder S, Persson T, Cotrufo MF, Ekblad A, Freeman M, Grelle A, Janssens IA, Jarvis PG, Kellomäki S, Lindroth A, Loustau D, Lundmark $T$, Norby RJ, Oren R, Pilegaard K, Ryan MG, Sigurdsson BD, Strömgren M, van Oijen M, Wallin G (2007) The likely impact of elevated [CO2], nitrogen deposition, increased temperature and management on carbon sequestration in temperate and boreal forest ecosystems: a literature review. New Phytol 173:463-480. https://doi.org/10.1111/j.1469-8137.2007.01967.x

IPCC (2013) Climate change 2013: the physical science basis. In: Stocker TF, Qin D, Plattner G-K, Tignor M, Allen SK, Boschung J, Nauels A, Xia Y, Bex V, Midgley PM (eds) Contribution of working group I to the fifth assessment report of the intergovernmental panel on climate change. Cambridge University Press, Cambridge, New York

Isbell Fl, Polley HW, Wilsey BJ (2009) Biodiversity, productivity and the temporal stability of productivity: patterns and processes. Ecol Lett 12:443-451. https:// doi.org/10.1111/j.1461-0248.2009.01299.x 
Jucker T, Avăcăriței D, Bărnoaiea I, Duduman G, Bouriaud O, Coomes DA (2016) Climate modulates the effects of tree diversity on forest productivity. J Ecol 104:388-398. https://doi.org/10.1111/1365-2745.12522

Jucker T, Bouriaud O, Avacaritei D, Coomes DA (2014a) Stabilizing effects of diversity on aboveground wood production in forest ecosystems: linking patterns and processes. Ecol Lett. n/a-n/a. https://doi.org/10.1111/ele.12382

Jucker T, Bouriaud O, Avacaritei D, Dănilă I, Duduman G, Valladares F, Coomes DA (2014b) Competition for light and water play contrasting roles in driving diversity-productivity relationships in Iberian forests. J Ecol 102:1202-1213. https://doi.org/10.1111/1365-2745.12276

Jump AS, Hunt JM, Peñuelas J (2006) Rapid climate change-related growth decline at the southern range edge of Fagus sylvatica. Glob. Change Biol. 12: 2163-2174. https://doi.org/10.1111/j.1365-2486.2006.01250.x

Kint V, Aertsen W, Campioli M, Vansteenkiste D, Delcloo A, Muys B (2012) Radial growth change of temperate tree species in response to altered regional climate and air quality in the period 1901-2008. Clim Chang 115:343-363. https://doi.org/10.1007/s10584-012-0465-x

Liang J, Crowther TW, Picard N, Wiser S, Zhou M, Alberti G, Schulze E-D, McGuire $A D$, Bozzato $F$, Pretzsch $H$, de Miguel S, Paquette A, Hérault B, SchererLorenzen M, Barrett CB, Glick HB, Hengeveld GM, Nabuurs GJ, Pfautsch S, Viana H, Vibrans AC, Ammer C, Schall P, Verbyla D, Tchebakova N, Fischer M, Watson JV, Chen HYH, Lei X, Schelhaas M-J, Lu H, Gianelle D, Parfenova El, Salas C, Lee E, Lee B, Kim HS, Bruelheide H, Coomes DA, Piotto D, Sunderland T, Schmid B, Gourlet-Fleury S, Sonké B, Tavani R, Zhu J, Brandl S, Vayreda J, Kitahara F, Searle EB, Neldner VJ, Ngugi MR, Baraloto C, Frizzera L, Bałazy R, Oleksyn J, Zawiła-Niedźwiecki T, Bouriaud O, Bussotti F, Finér L, Jaroszewicz B, Jucker T, Valladares F, Jagodzinski AM, Peri PL, Gonmadje C, Marthy W, O'Brien T, Martin EH, Marshall AR, Rovero F, Bitariho R, Niklaus PA, Alvarez-Loayza P, Chamuya N, Valencia R, Mortier F, Wortel V, Engone-Obiang NL, Ferreira LV, Odeke DE, Vasquez RM, Lewis SL, Reich PB (2016) Positive biodiversity-productivity relationship predominant in global forests. Science 354:aaf8957. https://doi.org/10.1126/science.aaf8957

Lindner M, Maroschek M, Netherer S, Kremer A, Barbati A, Garcia-Gonzalo J, Seidl R, Delzon S, Corona P, Kolström M, Lexer MJ, Marchetti M (2010) Climate change impacts, adaptive capacity, and vulnerability of European forest ecosystems. For Ecol Manag 259:698-709. https://doi.org/10.1016/j.foreco.2009.09.023

Loreau M, Hector A (2001) Partitioning selection and complementarity in biodiversity experiments. Nature 412:72-76

Loreau M, Naeem S, Inchausti P, Bengtsson J, Grime JP, Hector A, Hooper DU, Huston MA, Raffaelli D, Schmid B, Tilman D, Wardle DA (2001) Biodiversity and ecosystem functioning: current knowledge and future challenges. Science 294:804-808. https://doi.org/10.1126/science.1064088

Mencuccini M, Martínez-Vilalta J, Vanderklein D, Hamid HA, Korakaki E, Lee S, Michiels B (2005) Size-mediated ageing reduces vigour in trees. Ecol Lett 8 : 1183-1190. https://doi.org/10.1111/j.1461-0248.2005.00819.x

Morin X, Fahse L, Scherer-Lorenzen M, Bugmann H (2011) Tree species richness promotes productivity in temperate forests through strong complementarity between species. Ecol Lett 14:1211-1219

Ninemets Ü, Valladares F (2006) Tolerance to shade, drought, and waterlogging of temperate northern hemisphere trees and shrubs. Ecol Monogr 76:521547

Peters RL, Groenendijk P, Vlam M, Zuidema PA (2014) Detecting long-term growth trends using tree rings: A critical evaluation of methods. Glob Change Biol

Pinheiro J, Bates D, DebRoy S, Sarkar D, R Core Team (2016) \{nlme\}: Linear and Nonlinear Mixed Effects Models R package version 3, pp 1-128

Piovesan G, Biondi F, Filippo AD, Alessandrini A, Maugeri M (2008) Droughtdriven growth reduction in old beech (Fagus sylvatica L.) forests of the central Apennines, Italy. Glob. Change Biol 14:1265-1281. https://doi.org/10 1111/j.1365-2486.2008.01570.x

Pretzsch, H., Biber, P., 2016. Tree species mixing can increase maximum stand density. https://doi.org/10.1139/cjfr-2015-0413

Thomas FM, Blank R, Hartmann G (2002) Abiotic and biotic factors and their interactions as causes of oak decline in Central Europe. For Pathol 32:277307. https://doi.org/10.1046/j.1439-0329.2002.00291.x

Thorsen BJ, Mavsar R, Tyrväinen L, Prokofieva I, Stenger A (2014) The provision of forest ecosystem services: assessing cost of provision and designing economic instruments for ecosystem services. European Forest Institute, Joensuu
Toïgo M, Perot T, Courbaud B, Castagneyrol B, Gégout J-C, Longuetaud F, Jactel $H$, Vallet $P$ (2017) Difference in shade tolerance drives the mixture effect on oak productivity. J Ecol:1-10. https://doi.org/10.1111/1365-2745.12811

Tricot C, Vandiepenbeeck M, Van de Vyver H, Debontridder L (2015) De evolutie van het klimaat in België in Oog voor het klimaat. Koninklijk Meteorologisch Instituut van België, Brussel

Trouvé R, Bontemps J-D, Seynave I, Collet C, Lebourgeois F (2015) Stand density, tree social status and water stress influence allocation in height and diameter growth of Quercus petraea (Liebl.). Tree Physiol 35:1035-1046. https://doi.org/10.1093/treephys/tpv067

Van de Peer T, Verheyen K, Kint V, Van Cleemput E, Muys B (2017) Plasticity of tree architecture through interspecific and intraspecific competition in a young experimental plantation. For Ecol Manag 385:1-9. https://doi.org/10. 1016/j.foreco.2016.11.015

Vannoppen A, Boeckx P, De Mil T, Kint V, Ponette Q, Van den Bulcke J, Verheyen K, Muys B (2018) Climate driven trends in tree biomass increment show asynchronous dependence on tree-ring width and wood density variation. Dendrochronologia 48:40-51. https://doi.org/10.1016/j.dendro.2018.02.001

Verheyen K, De Frenne P, Baeten L, Waller DM, Hédl R, Perring MP, Blondeel H, Brunet J, Chudomelová M, Decocq G, De Lombaerde E, Depauw L, Dirnböck T, Durak T, Eriksson O, Gilliam FS, Heinken T, Heinrichs S, Hermy M, Jaroszewicz B, Jenkins MA, Johnson SE, Kirby KJ, Kopecký M, Landuyt D, Lenoir J, Li D, Macek M, Maes SL, Máliš F, Mitchell FJG, Naaf T, Peterken G, Petřík P, Reczyńska K, Rogers DA, Schei FH, Schmidt W, Standovár T, Świerkosz K, Ujházy K, Van Calster H, Vellend M, Vild O, Woods K, Wulf M, Bernhardt-Römermann M (2017) Combining biodiversity resurveys across regions to advance global change research. BioScience 67:73-83. https://doi. org/10.1093/biosci/biw150

Verstraeten A, Sioen G, Neirynck J, Roskams P, Maaten H (2012) Bosgezondheid in Vlaanderen. In: Bosvitaliteitsinventaris, meetnet Intensieve Monitoring Bosecosystemen en meetstation luchtverontreiniging. Resultaten 2010-2011, p 64

VMM, 2017. Stikstofdepositie [WWW Document]. Milieurapport Vlaan. MIRA. URL https://www.milieurapport.be/milieuthemas/vermesting-verzuring/ vermesting/stikstofdepositie

Wykoff WR (1990) A basal area increment model for individual conifers in the northern Rocky Mountains. For Sci 36:1077-1104

Zhang Y, Chen HYH, Reich PB (2012) Forest productivity increases with evenness, species richness and trait variation: a global meta-analysis. J Ecol 100:742749. https://doi.org/10.1111/j.1365-2745.2011.01944.x

Zuur AF, leno EN, Walker N, Saveliev AA, Smith GM (2009) Mixed effects models and extensions in ecology with $\mathrm{R}$, statistics for biology and health. Springer New York, New York, NY

\section{Submit your manuscript to a SpringerOpen ${ }^{\circ}$ journal and benefit from:}

- Convenient online submission

Rigorous peer review

- Open access: articles freely available online

- High visibility within the field

- Retaining the copyright to your article

Submit your next manuscript at $>$ springeropen.com 